\title{
ESZKÖZHASZNÁLATRA UTALÓ FOGAZATI ELVÁLTOZÁS SZALASZEND- NAGY- ÉS KISHEGY HONFOGLALÁS KORI (10. SZÁZADI) TEMETŐJÉBŐL
}

\author{
Mateovics-László Orsolya ${ }^{1}$ - Líbor Csilla ${ }^{2}$ \\ Magyar Régészet 10. évf. (2021), 1. szám, pp. 22-29. https://doi.org/10.36245/mr.2021.1.4
}

A Magyar Nemzeti Múzeum Régészeti és Örökségvédelmi Igazgatósága 2018 tavaszán kezdte meg az M30-as autópálya épitéséhez kapcsolódó megelözö régészeti feltárásait. A Szalaszend-Nagy-és Kishegy nevü lelöhely egy bronzkori földvártól délre fekvö területen került elö, ahol a 10. századi anyagot csupán néhány temetkezés képviselte, mégis egy igen fontos régészeti és embertani információt hordozó leletegyüttest rejtett magában. Embertani szempontból a legjelentösebb sír az SNR 407. számú férfié volt, akinek a maradványai sajátos módon engedtek betekintést a 10. századi népesség életmódjába. Az itt megfigyelt fogzománc-elváltozás olyan foglalkozáshoz kapcsolódó tevékenységhez köthetö, amelyhez mindkét kézre szükség van, és egy szilárd, kemény tárgyat a fogak között kellett tartani, esetleg mozgatni.

Kulcsszavak: honfoglaláskor, kora középkor, életmód, temetkezés, embertan, fogazati elváltozás

Az embertani kutatások módszertani fejlődése, valamint az egyre nagyobb számú leletanyagon végzett vizsgálatok olyan egyedi esetek előkerülését is eredményezik, amelyek új kérdésköröket vetnek fel. Egy ilyen lelet vezetett bennünket a hazai tanulmányokból csak ritkán ismert területhez, nevezetesen az egykori ember eszközhasználatra utaló fogazati elváltozásainak kutatásához. Bizonyos tevékenységekre utaló csonttani elváltozások (izomeredési és -tapadási helyek elváltozásai, enthesopathiák) vizsgálata már jól ismert, melyek által akár egészen specifikusan is meghatározható, hogy milyen fizikai aktivitás köthető a vázrendszeren tapasztalt morfológiai jellegzetességekhez. Ilyen aktivitás például a lovas életmód vagy az ijászat (Tihanyi et al. 2015). A fogazat - bár ritkábban - ugyancsak utalhat az egyén életében végzett tevékenységre, vagyis nem csak a táplálkozással összefüggő szokásokról nyújt információt. Ezek a fogazati elváltozások jellegzetes fogkopás formájában jelzik a mechanikai behatás, az eszközhasználat nyomait. Az újkori népességekben olyan specifikus foglalkozások is beazonosíthatók általuk, mint a cipökészítés vagy az asztalos mesterség (Bonfiglioli et al. 2004). Ennek egyik leglátványosabb példája egy 30-40 éves férfi Angliából, aki valószínüleg ács lehetett, és a szögletes alakú szögek szájban tartása a frontfogak oldalsó élein mély, konkáv, éles peremü csiszolódásokat okozott (TuRNER \& ANDERSON 2003).

Számunkra Szalaszend-Nagy- és Kishegy honfoglalás kori lelőhelye szolgáltatott kivételes lehetőséget arra, hogy az egykori ember mindennapi életébe ilyen sajátos módon kaphassunk betekintést, egyúttal elsőként bizonyítva ennek a ritka fogazati jelenségnek a jelenlétét nemcsak a korszakban, de hazánk területén is.

\section{A LELÖHELY}

A 10. századi temetkezési hely a Hernád-völgy nyugati peremén húzódó dombvonulaton, egy hajdan időszakos vízmosás déli partján jött létre (LíBor \& TAKÁcs 2019; TAKÁcs \& PuszTai 2019; SzörÉNYi \& PuszTAi 2020; 1-2. kép). A sírok közös jellemzője a csontok rossz megtartása volt. A sírokat valószínüleg korabeli rablásokkal rongálták meg, így a vázak különböző mértékben hiányosak voltak. A bolygatások mindegyik temetkezés esetében a felsőtestet és a medencetájékot érintették. A nyolc temetkezés között egy gyermek, három férfi, két nő és két nem meghatározható nemü egyén volt. A sírokba adultus és maturus korú egyéneket temettek.

\footnotetext{
Magyar Nemzeti Múzeum, Régészeti Örökségvédelmi Igazgatóság, Budapest. E-mail: laszlo.orsolya@hnm.hu

2 Szent István Király Múzeum, Székesfehérvár; Eötvös Loránd Tudományegyetem, Biológiai Doktori Iskola, Budapest. E-mail: libor.csilla@szikm.hu
} 


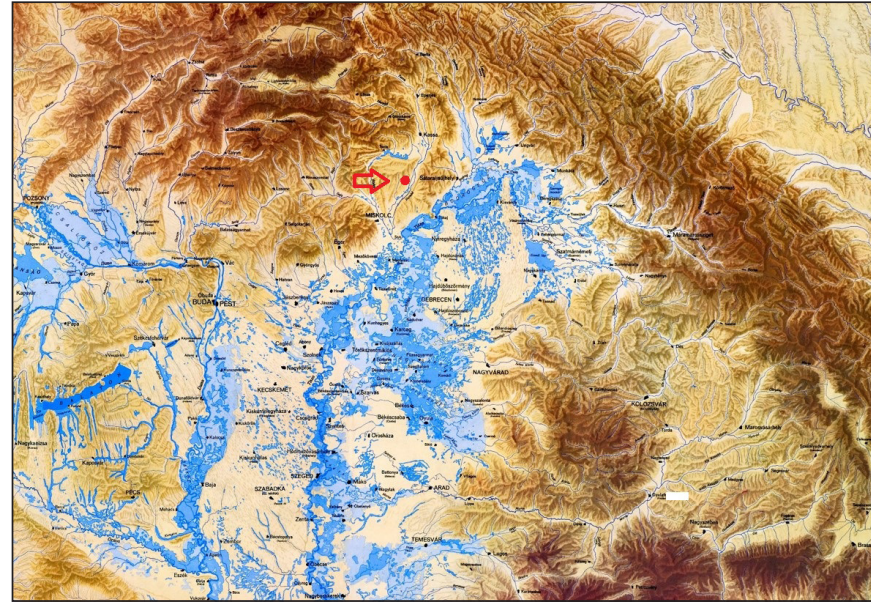

1. kép. A lelöhely elhelyezkedése

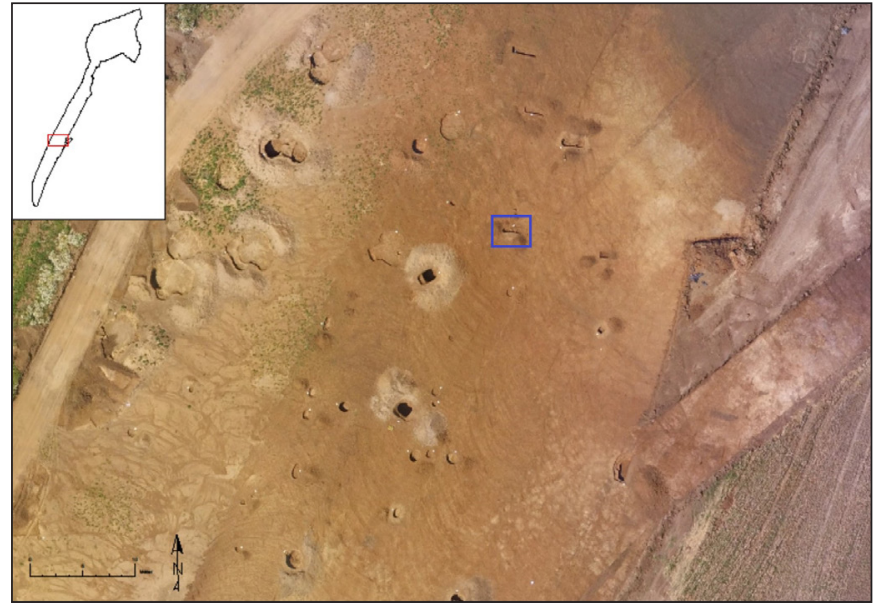

2. kép. A lelőhelyröl készült légi felvétel (fotó: Pokorni László)

\section{SNR 407. SZÁMÚ EGYÉN}

A sírból egy 23-27 éves férfi (ÉRY, Kraloványszky \& Nemeskéri 1963; Lovejoy et al. 1985; Brooks \& Suchey 1990) rossz megtartású maradványai kerültek napvilágra (3-4. kép). A koponya és a váz hiányos volt. Az egyént háton fekvő pozícióban találtuk, a lábszár csontjai anatómiai rendben voltak, míg a koponya a hasi részen került elő. Rablógödör foltját nem sikerült azonosítanunk. A sírból a medencecsont alól elökerült egy négyzet alakú ezüstlemez, amin a bontás során aranyozás nyomait figyeltük meg. Funkciója ismeretlen, valószínüleg övveret lehetett. A vázcsontok között íjmarkolat csontlemeze került elő (4. kép). A koponyán és a vázcsontokon kóros elváltozás nem volt észlelhető.

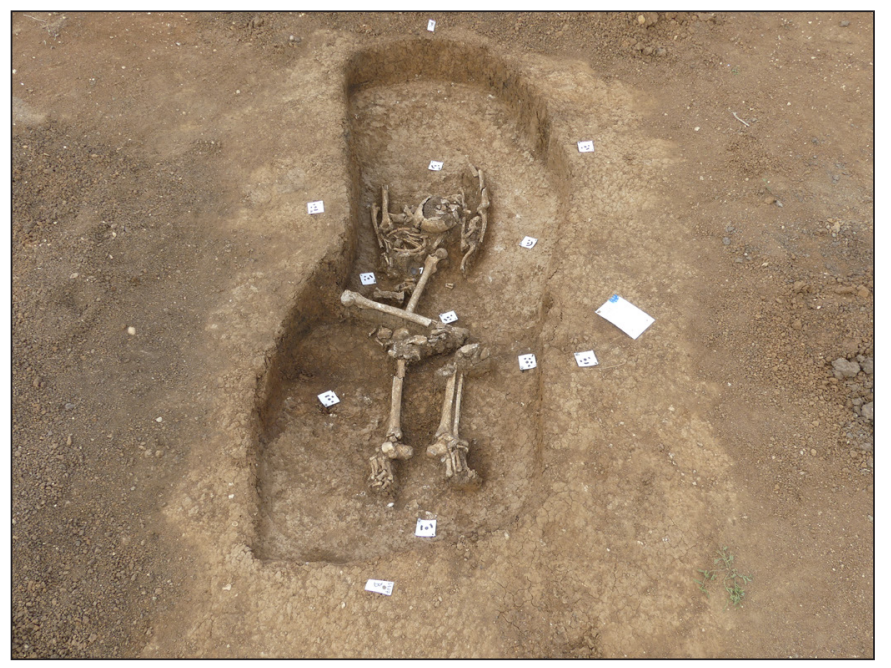

3. kép. Az SNR 407. számú sírról készitett fotódokumentáció (fotó: Libor Csilla)

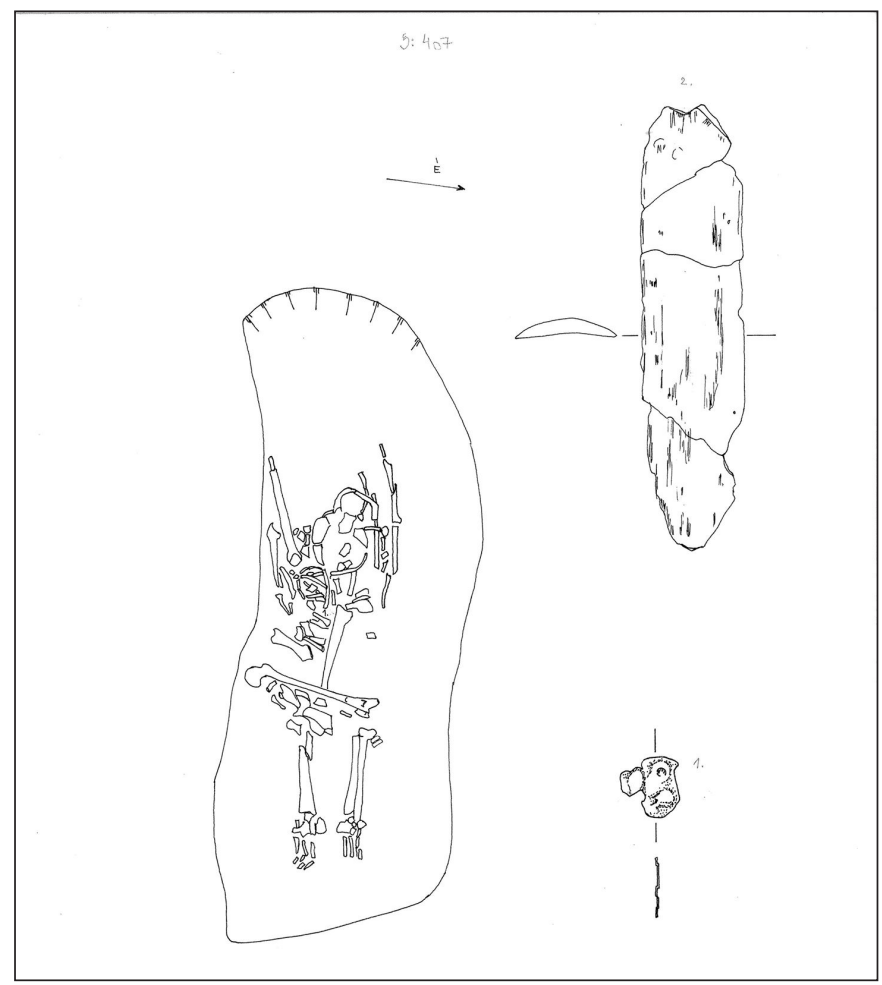

4. kép. Az SNR 407. számú sírról készült rajzdokumentáció az ovális alakú markolatcsontról készült részletrajzzal (rajz: Szénásy Csaba, Kazsóki Ágnes)

\section{AZ EGYÉN FOGAZATÁNAK RÉSZLETES ELEMZÉSE}

A férfi fogazatából a felső harmadik és a jobb második nagyőrlők postmortem hiányoztak. A férfi fogai az életkorának megfelelő mértékű fogkopást mutattak. A kopás mértéke csak az első nagyőrlők esetében volt előrehaladottabb, vagyis apróbb foltokban a zománc alatti dentinállomány is megmutatkozott. A bal alsó második met- 


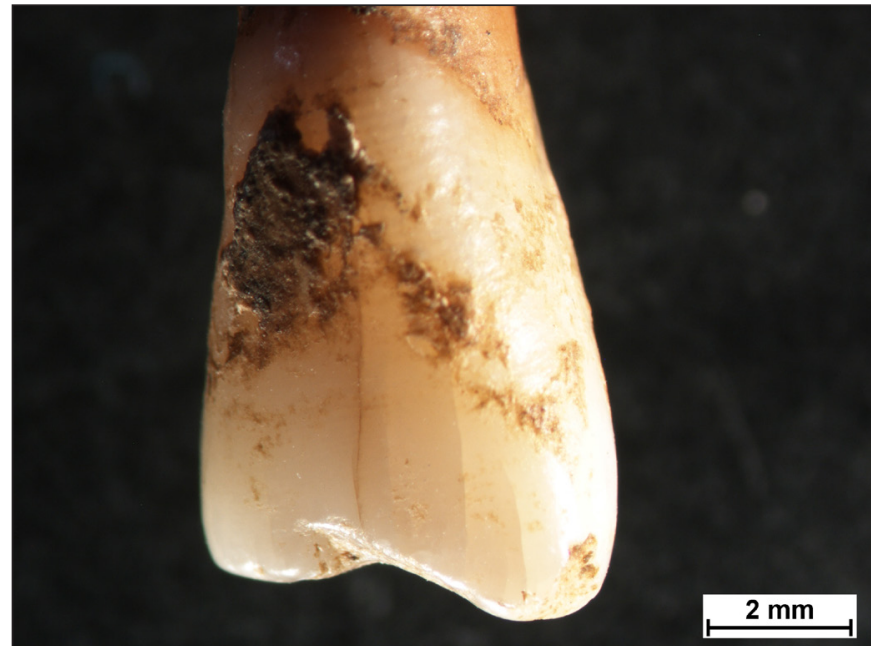

5. kép. A bal második metszőfog labialis nézete az eszköztöl származó kopásnyommal

szőfog esetében sajátos kopási mintát tapasztaltunk. A kopásnyom a metszőélre merőlegesen (buccalislabialis, tehát keresztirányban), annak középvonalában alakult ki, amely a zománcréteg alatti dentint is elérte. A bemélyedés az ajkak felőli (labialis) oldalon V-alakban a metszőél felé kiszélesedik, a V csúcsában élesen beszükül, és enyhén ferdén balra tart (5-6. kép). A vájat a nyelv felöli (lingualis) oldalon lefelé ívelt, a pereme éles, és apró ívek által csipkézett mintázatot ad (7-9. kép). A kopásnyom felszíne sárgás színü, talaj általi elszíneződést mutat, vagyis a postmortem roncsolás, a friss törés kizárható. A felszín kopása még halál előtti behatásnak tulajdonítható.
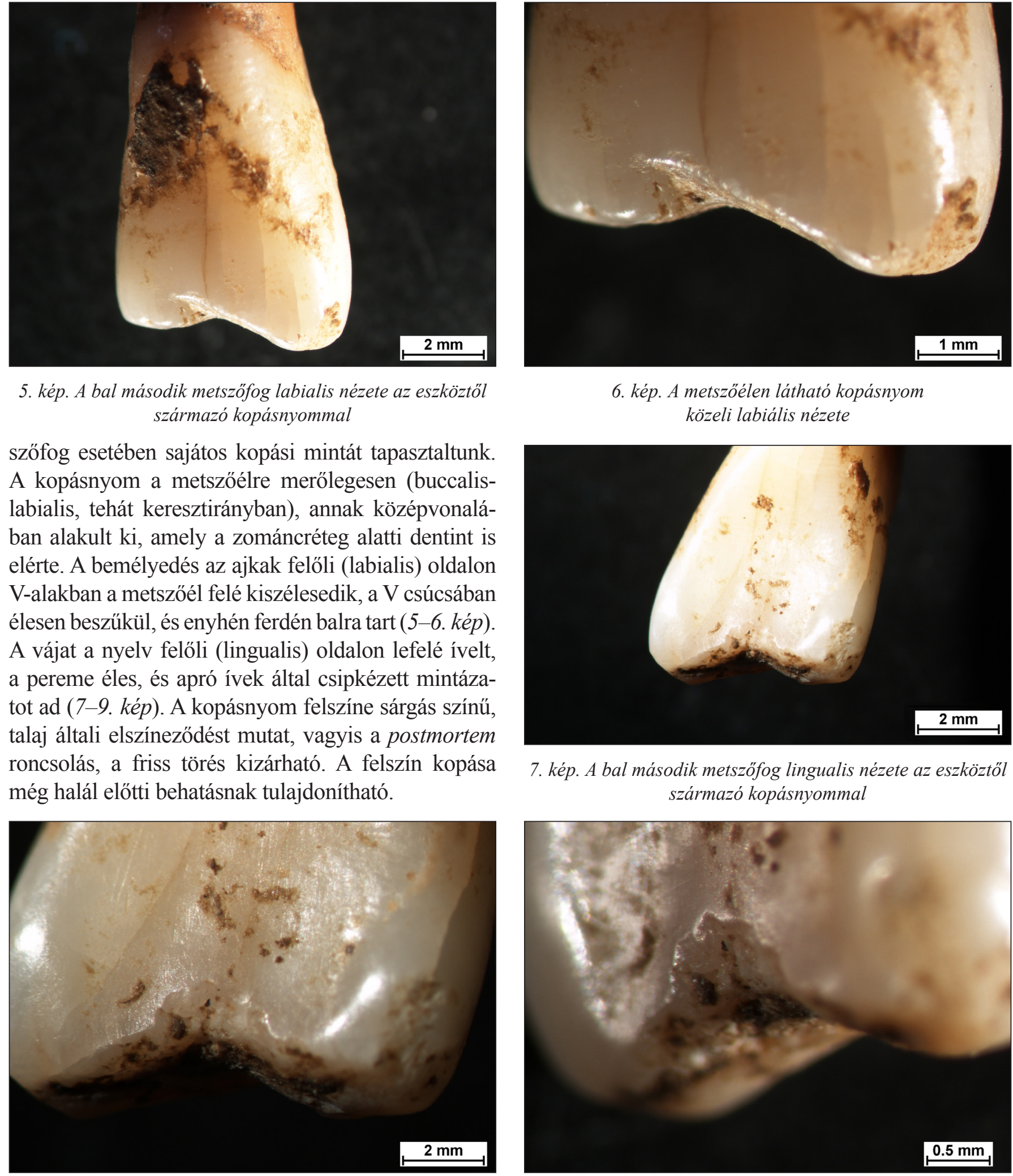

6. kép. A metszőélen látható kopásnyom közeli labiális nézete

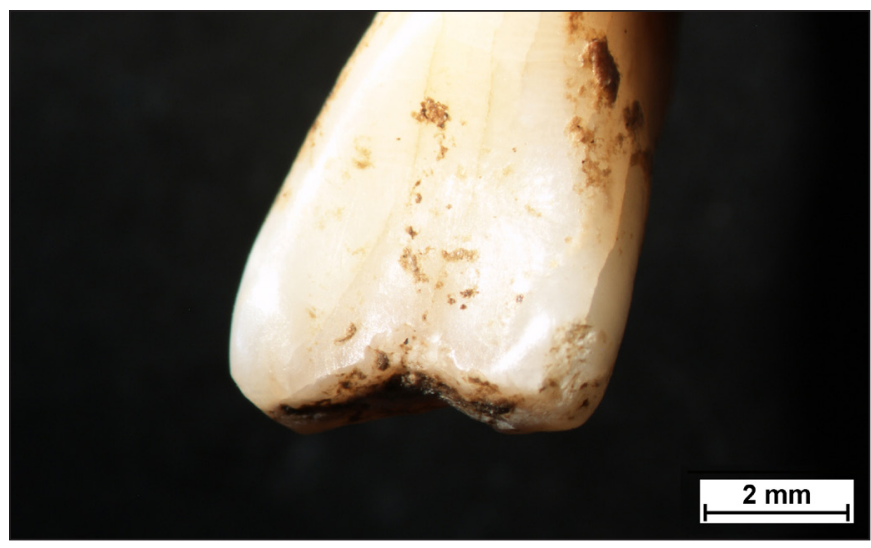

7. kép. A bal második metszőfog lingualis nézete az eszköztöl származó kopásnyommal

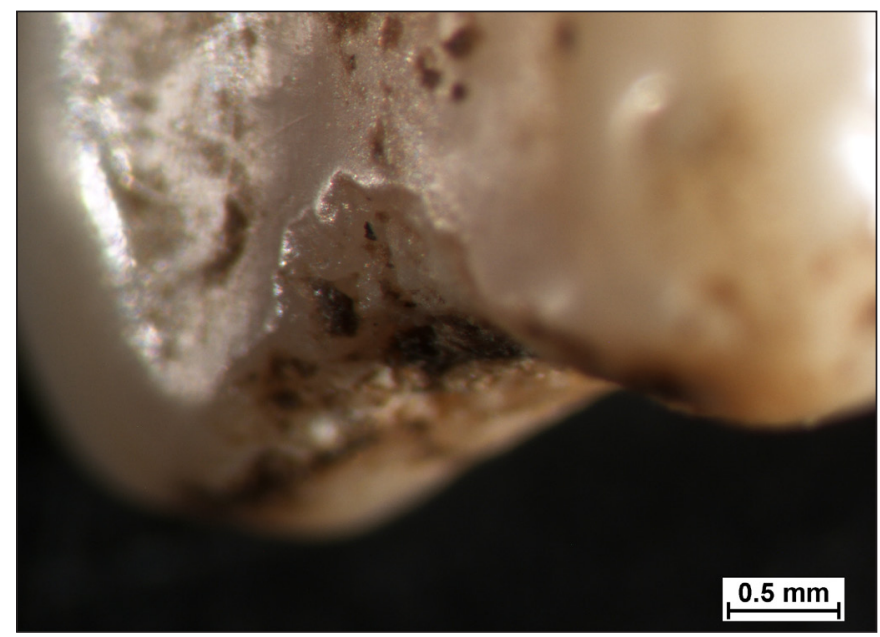

8-9. kép. A metszőélen látható kopásnyom közeli lingualis nézete

\section{A FOGAK MINT ÉLETMÓDJELZŐ LELETEK}

Az életkor elörehaladtával a fogaink folyamatosan kopnak, melynek mértékére és mintázatára a táplálék összetétele nagy hatással bír. A fogkopás kezdetben kisebb csiszolt felületeket hoz létre a fogzománcon, mely az idő múlásával a zománc által védett dentint is feltárhatja, később egyre nagyobb területeket érintve végül a gyökérzónáig is eljuthat. A fogkopás a jellege alapján lehet: attríció, erózió és abrázió. 
Az attríció a fogak normál, nem patológiás mértékü kopását jelenti, amely az életkor elörehaladtával minden fogon megjelenik (HILLSON 1996). A táplálék koptató hatása mellett fogszövetvesztés létrejöhet a rágófunkció vagy bruxizmus (fogcsikorgatás) következtében is, fog-foggal való érintkezése során. A frontfogak kopása általában mesialis-lateralis irányú (jobb-bal oldal felé irányuló), amit az alsó és felső frontfogak egymáson való csiszolódása okoz. Ez variálódhat, ha felül- vagy alulharapásról van szó, ami azt jelenti, hogy a felső fogazat előrébb vagy - az utóbbi esetben - hátrébb áll, mint az alsó. Ezekben az esetekben az egymással érintkező metszőfogakon nem a metszőfelszínen, hanem a nyelv (lingualis) vagy az ajkak felőli (labialis) oldalon tapasztalhatunk kopást. Természetesen egyedi mintázatok is megjelenhetnek, amennyiben fejlődési rendellenesség (fogtorlódás, fogelfordulás) alakult ki, de ezek egyértelműen beazonosíthatóak a fogak helyzete alapján. Mivel a szalaszendi egyénnél a kopás iránya meglehetősen eltér az általános kopási mintázattól, azt bizonyosan nem a fogak egymással való érintkezése okozta.

Kiváltó tényezőként az erózió is kizárható ebben az esetben, mivel azt külső savas behatás hozza létre, mint például a reflux, a hányás vagy a modern népességekben a szénsavas ital fogyasztása (HILLSON 1996).

A szalaszendi férfinél a kopás morfológiája, alakja azt sugallja, hogy egy vékony, szilárd anyag egy irányban történő mozgatása vezetett a zománc lecsiszolódásához. Ez a fogfelszíni elváltozás az abrázió egy speciális fajtájába sorolható. Abrázió esetén nem a fogak rágás miatt kialakuló kopásáról, hanem annak csiszolódásáról beszélünk, amit egy ismétlődő, hosszú ideig fennálló, foggal végzett tevékenység vagy tárggyal való érintkezés idéz elő. Négy kategóriát különböztetünk meg ezen belül: 1. szándékos csonkítás; 2. nem szándékos, eszköztől származó elváltozás; 3. szájápolási technikából eredő; 4. foglalkozásból eredő abrázió.

1. A szándékos csonkítás gyakran összetéveszthető az eszköztől származó elváltozásokkal, de ezek célja leginkább esztétikai, vagy pedig szimbolikus jelentésekkel bír. Ilyen szándékos csiszolatnyomokat ismerünk a viking korszakból (ARCINI 2020), valamint ide sorolhatóak az amerikai szériákban megfigyelt ajakékszerek viselésének nyomai (CYBULSKi 1974; TORRES-RoufF 2003).

2. Nem szándékos, eszköztől származó elváltozásokat nem táplálkozáshoz köthető eszközök szájban tartása vagy mozgatása okozhat. Ennek egyik legjellegzetesebb példája a kör/félkör alakú „,pipaszár kopás” (pipe facet), amely az európai szériákban a 18. századtól figyelhető meg. Ezt a típusú kopást hazánkban Perkáta-Nyúli dülő rác 16-17. századi temetöjében is sikerült kimutatni (Mateovics-LÁszló, közöletlen; 10. kép; KvaAl \& Derry 1996). Modern népességekben ilyen elváltozásokat okozhat a fogkefe vagy a zeneszerszám használata.

3. Két szomszédos fog között a fognyakon a fogzománc és a cement találkozásánál jelenhetnek meg ún. interproximalis vájatok, melyek a fogvájás nyomait jelzik (Berryman, Owsley \& Henderson 1979;

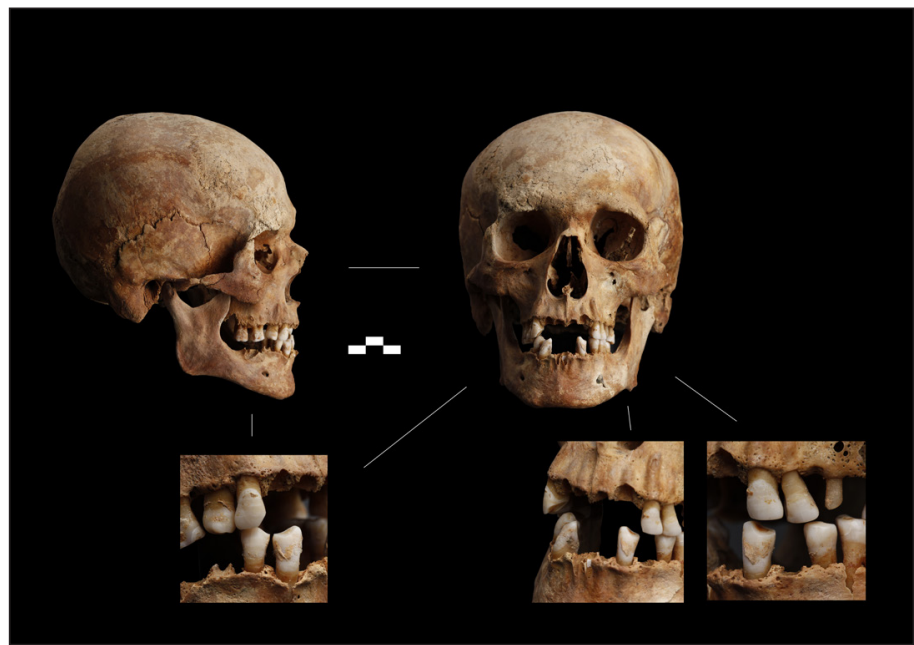

10. kép. Pipaszár által okozott kerek kopásnyom Perkáta-Nyúli dülö rác temetőjéböl. A kerek alakú kopásnyom a jobb felsö és alsó elsö kisőrlök és a szemfog között alakult ki. A bal oldalon az alsó szemfogon is látható hasonló ívelt vápa (SNR 2024, 30-39 éves férfi) (fotó: Bicskei József, MNM, RÖG) FrAYER 1991), és már a hominidákon is leírtak (Frayer \& Russell 1987; Bermudez de Castro, Arsuaga \& Perez 1997).

4. A foglalkozásból eredő fogzománc-elváltozások olyan tevékenységekhez köthetőek, amelyek esetében mindkét kézre szükség van, de egy szilárd, kemény tárgyat a fogak között is tartani, esetleg mozgatni kell (CRUwys, RoBb \& Sмiтh 1992). A szalaszendi sír egyértelmüen ebbe a kategóriába sorolható. 
Mateovics-László Orsolya - Líbor Csilla • Eszközhasználatra utaló fogazati elváltozás

\section{PÁRHUZAMOK KERESÉSE: VAN-E MEGFEJTÉS?}

A hazai szériákon végzett fogazati vizsgálatok elsősorban a táplálkozással összefüggő elváltozásokra, illetve a nem-metrikus variációkra, fejlődési rendellenességekre terjednek ki (Kocsis 1988; SzIKossy \& BERNERT 1996; MACZEL et al. 1998). Eszközhasználatot kimutató közlés eddig nálunk nem ismert, de a nemzetközi szakirodalomban is igen ritkán fordul elő. Az eszköz általi kopásnyomok specifikus morfológiával, lokalizációval rendelkeznek, így a kopást okozó tárgynak, tevékenységnek a meghatározásában csak közölt esetek segíthetnek.

A szalaszendi egyén fogazatának elváltozása morfológia és lokalizáció szempontjából olyan példákkal mutat hasonlóságot, ahol a vájatokat növényi vagy állati rostok, szövetszálak fogak között való mozgatásának vagy tartásának tulajdonítják, és ezek feldolgozásával függ össze (LARSEN 1985; MoLLESON 1994). Ezekben az esetekben a frontfogak, a szemfogak és a kisőrlők voltak érintettek. Rostos szerkezetủ ínak húzogatása a fogak között az alsó nyaki részen, a kis- és nagyőrlőkön hozhat létre (approximalis) vájatot, vagy a frontfogak metszőélén, de azzal párhuzamosan (Brown \& Molnar 1990; Milner \& LaRsen 1991). Ezt a jelenséget 19. századi ausztrál őslakosok maradványain mutatták ki, és inkább a férfiakra volt jellemző. A szerzők feltételezését megerősítették azok a filmfelvételek is, amelyeken az őslakosokat megörökítették e tevékenység közben (BROwn \& MoLNAR 1990). Növényi rostos szerkezetü anyagok feldolgozásának - mint pl. kosár-, hálófonás - tulajdonították egy amerikai prekolumbián mintán az állkapocs frontfogain megfigyelt rágófelszíni és approximális vájatokat (SchULz 1977; LARSEN 1985). Ezek a típusú kopásnyomok egy átfogó brit kutatás során az angolszász periódusban is felfedezhetőek voltak (CRuwys, Roвb \& Sмiтн 1992). A kopásnyomok mindkét esetben a férfiakra voltak inkább jellemzőek. Perkáta-Nyúli dűlő kun (13-16. század) népességében hasonló V-alakú barázdákat találtunk három női egyén alsó metszőfogain (MATEOvics-LÁszló, közöletlen). Ezeknél az eseteknél is vékonyabb, de jól bemélyedő vápa alakult ki (11. kép).

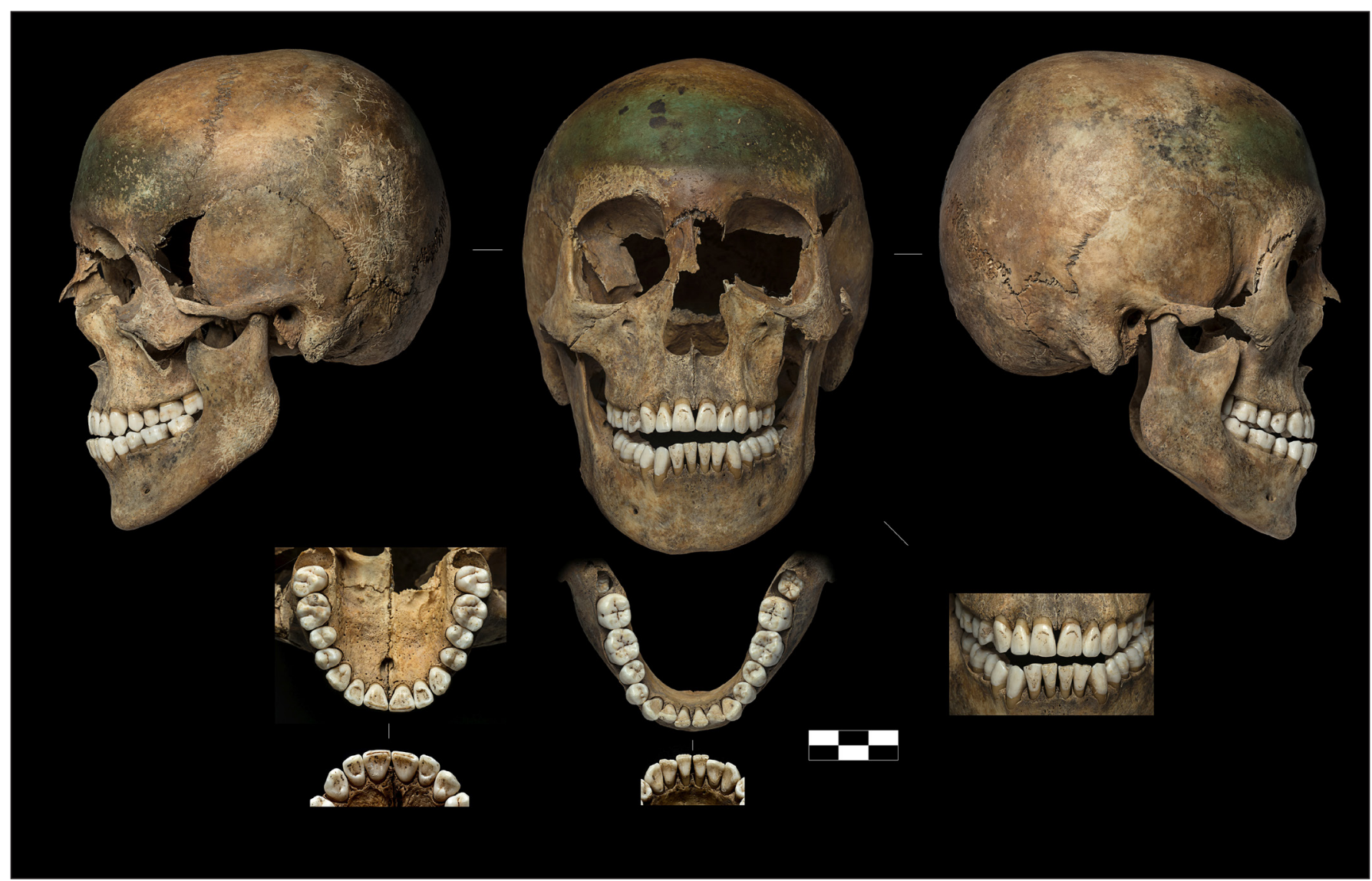

11. kép. V-alakú barázda egy 15-17 éves nö bal alsó második metszöfogán (SNR 1038) Perkáta-Nyúli dülö kun temetőjéböl (fotó: Bicskei József, MNM, RÖG) 
A foghasználat történhet a gyapjú, kender, len fonalba fonása során is. A fonal készítése lényegében a nyers szálak kihúzását és elcsavarását jelenti annak érdekében, hogy a véges méretü nyers szálakból folyamatos hosszúságú szálat képezzenek (EMERY 1994). A gyapjú szennyeződéseinek (pl. bolyhok) eltávolítása lényeges lépés a fonal felpörgetése előtt, ugyanis ezek a hibák egyenetlenné teszik a fonalat, ami megnehezíti a későbbi munkát vele. Ezt foggal végezték, mivel a két kéz a fonal felpörgetéséhez kellett. Varráskor ugyanazt a húzó- és harapási műveletet alkalmazhatják, de ekkor a fonal vágásának a céljából teszik ezt (SCOTT \& Jolie 2008). A szövés és a fonás elsősorban a nők körében megfigyelt tevékenység, így feltételezzük, hogy a szalaszendi férfinél más cselekvés nyoma mutatkozhat meg hasonló morfológiai jellegekkel. Ray Wood (1992) ezt a jelenséget figyelte meg inuit eszkimóknál is, ahol a metszőélre merőleges irányú vájatokat a nőknél a fogak közé szorított tü, rost okozta, a férfiaknál viszont az állati ínból származó szálak tartása. Az állati ín felhasználása (pl. íjhúrhoz, kötélhez) jellemző több népességben is (SCOTт \& TURNER 1988). Tekintettel arra, hogy ebben a sírban íjászathoz köthető tárgy is elökerült, a honfoglaló férfi esetében sem zárható ki, hogy élete során ehhez köthető eszközkészítö, anyagfeldolgozó tevékenységeket végezhetett.

\section{Ő AZ EGYETLEN?}

Annak ellenére, hogy a szalaszendi és a perkátai temető eltérő népességekhez tartozik, és a használatuk időben is igen távol esik egymástól, mindkét népesség keleti gyökerekkel rendelkezik. Ez jól mutatja, hogy korszaktól függetlenül is megtalálhatóak mindkét népesség embertani hagyatékában a speciális tevékenységek nyomai, amennyiben az életmódban, a szokásokban hasonlóságok lelhetők fel. Így célszerü lenne nemcsak több honfoglaló és kun szérián, de akár korábbi, keleti eredetű elemeket tartalmazó avar temetőkben is tovább vizsgálni ezt a kérdéskört.

\section{BIBLIOGRÁFIA}

Arcini, C. (2020). Intentionally Modified Teeth Among the Vikings: Was It Painful? In S. Sheridan \& L. Gregoricka (eds.), Purposeful Pain. Bioarchaeology and Social Theory (pp. 137-148). Springer, Cham. https://doi.org/10.1007/978-3-030-32181-9 7

Bermudez de Castro, J. M., Arsuaga, J. L. \& Perez, P. J. (1997). Interproximal grooving in the AtapuercaSH Hominid dentitions. American Journal of Physical Anthropology 102, 369-376. https://doi.org/10.1002/ (sici)1096-8644(199703)102:3\%3C369::aid-ajpa6\%3E3.0.c0;2-q

Berryman, H. E., Owsley, D. W. \& Henderson, A. M. (1979). Noncarious interproximal grooves in Arikara Indian dentitions. American Journal of Physical Anthropology 50, 209-212. https://doi.org/10.1002/ ajpa.1330500209

Bonfiglioli, B., Mariotti, V., Facchini, F., Belcastro, M. G. \& Condemi, S. (2004). Masticatory and nonmasticatory dental modifications in the Epipalaeolithic necropolis of Taforalt (Morocco). International Journal of Osteoarchaeology 14, 448-456. https://doi.org/10.1002/oa.726

Brooks, S. \& Suchey, J. M. (1990). Skeletal age determination based on the os pubis: A comparison of the Acsádi-Nemeskéri and Suchey-Brooks methods. Human Evolution 5, 227-238. https://doi.org/10.1007/ $\underline{B F 02437238}$

Brown, T. \& Molnar, S. (1990). Interproximal grooving and task activity in Australia. American Journal of Physical Anthropology 81, 545-553. http://doi.org/10.1002/ajpa.1330810410 
Mateovics-László Orsolya - Líbor Csilla • Eszközhasználatra utaló fogazati elváltozás

Cruwys, E., Robb, N. D. \& Smith, B. G. N. (1992). Anterior tooth notches: An Anglo-Saxon case study. Journal of Paleopathology 4, 211-220.

Cybulski, J. S. (1974). Tooth wear and material culture: Precontact patterns in the Tsimshian area, British Columbia. Syesis 7, 31-35.

Emery, I. (1994). The Primary Structures of Fabrics: An Illustrated Classification. Watson Guptill Publications - Whitney Library of Design, the Textile Museum, Washington, D.C.

Éry, K., Kralovánszky, A. \& Nemeskéri, J. (1963). Történeti népességek rekonstrukciójának reprezentációja. Anthropológiai Közlemények 7, 41-90.

Formicola, V. (1988). Interproximal grooving of teeth: Additional evidence and interpretation. Current Anthropology 29 (4), 663-671.

Frayer, D. W. (1991). On the etiology of interproximal grooves. American Journal of Physical Anthropology 85, 299-304. https://doi.org/10.1002/ajpa.1330850308

Frayer, D. W. \& Russell, M. D. (1987). Artificial grooves on the Krapina Neanderthal teeth. American Journal of Physical Anthropology 74, 393-405. https://doi.org/10.1002/ajpa.1330740311

Hillson, S. (1996). Dental Anthropology. Cambridge: Cambridge University Press. https://doi.org/10.1017/ CB09781139170697

Kocsis, S. G. (1988). Hódmezővásárhely Gorzsa-Czukor major újkőkori temető embertani anyagának fogantropológiai és patológiai leírása. A Móra Ferenc Múzeum Évkönyve 1987 (1), 69-79.

Kvaal, S. I., Derry, T. K. (1996). Tell-tale teeth: abrasion from the traditional clay pipe. Endeavour 20 (1), 28-30. https://doi.org/10.1016/0160-9327(96)10006-5

Larsen, C. S. (1985). Dental modifications and tool use in the western Great Basin. American Journal of Physical Anthropology 67 (4), 393-402. https://doi.org/10.1002/ajpa.1330670411

Libor, Cs. \& Takács, R. (2019). The conquerors of the Hernád Valley - Details from the history of a region. Hungarian Archaeology 8 (3), 28-34. https://doi.org/10.36338/ha.2019.3.9

Lovejoy, C. O., Meindl, R. S., Mensforth, R. P. \& Barton, T. J. (1985). Multifactorial determination of skeletal age at death: A method with blind tests of its accuracy. American Journal of Physical Anthropology 68 (1), 1-14. https://doi.org/10.1002/ajpa.1330680102

Lozano, M., Jiménez-Brobeil, S. A., Willman, J. C., Sánchez-Barba, L.P., Molina, F. \& Rubio Á. (2020). Argaric craftswomen: Sex-based division of labor in the Bronze Age southeastern Iberia. Journal of Archaeological Science. In press, corrected proof. https://doi.org/10.1016/j.jas.2020.105239

Maczel M., Kocsis S.G., Marcsik A., Molnár E. (1998). Dental disease in the Hungarian conquest period. Bulletins et Mémoires de la Société d'anthropologie de Paris, Nouvelle Série 10 (3-4), 457-470. https:// doi.org/10.3406/bmsap.1998.2530

Milner, G. R. \& Larsen, C. S. (1991). Teeth as Artifacts of Human Behavior: Intentional Mutilation and 
Mateovics-László Orsolya - Líbor Csilla • Eszközhasználatra utaló fogazati elváltozás

Accidental Modification. In M. A. Kelley and C. S. Larsen (eds.), Advances in Dental Anthropology (pp. 357-378). New York: Wiley-Liss.

Molleson, T. (1994). The eloquent bones of Abu Hureyra. Scientific American 271 (2), 70-75. https://doi. org/10.1038/ scientificamerican0894-70

Ray-Wood, S. (1992). Tooth wear and sexual division of labour in an Inuit population. BA thesis. Simon Fraser University, Department of Archaeology.

Schulz, P. D. (1977). Task activity and anterior tooth grooving in prehistoric California Indians. American Journal of Physical Anthropology 46, 87-92. https://doi.org/10.1002/ajpa.1330460112

Scott, G. R. \& Jolie, R. B. (2008). Tooth-tool use and yarn production in Norse Greenland. Alaska Journal of Anthropology 6 (1-2), 253-264.

Scott, G. R. \& Turner, C. G. (1988). Dental Anthropology. Annual Review of Anthropology 17, 99-126. https://doi.org/10.1146/annurev.an.17.100188.000531

Szikossy, I. \& Bernert, Zs. (1996). A Kereki-Homokbánya temető paleosztomatológiai vizsgálata (Paleostomatological study of the Avar Age cemetery at Kereki-Homokbány). In Gy. Farkas \& Gy. Pálfi (eds.) Honfoglaló magyarság - Árpád kori magyarság (pp. 189-198). Szeged: JATE Embertani tanszék.

Szörényi, G. \& Pusztai, T. (2020). Hét metszet a Hernád folyó völgyéből. Az M30-as Miskolc-Kassa autópálya építését megelőző régészeti feladatellátás és kutatás. Herman Ottó Múzeum Évkönyve 2020, $103-148$.

Takács, R. \& Pusztai, T. (2019). A Hernád-völgy 10-11. századi településtörténetéhez. In B. Sudár \& A. Türk (eds.), „Hadak útján”- A népvándorláskor fiatal kutatóinak XXIX. Konferenciája. Budapest, 2019. november 15-16. Absztrakt kötet (pp. 86-87). Budapest: Bölcsészettudományi Kutatóközpont Magyar Őstörténeti Témacsoport - Pázmány Péter Katolikus Egyetem Régészettudományi Intézet - Martin Opitz Kiadó.

Tiesler, V., Cucina, A. \& Ramirez-Salomon, M. (2017). Permanent Dental Modifications among the Ancient Maya: Procedures, Health Risk, and Social Identities. In S. E. Burnett \& J. D. Irish (eds.), A World View of Bioculturally Modified Teeth (pp. 270-284). Gainesville: University Press of Florida.

Tihanyi, B., Bereczki, Zs., Molnár, E., Berthon, W., Révész, L., Dutour, O. \& Pálfi, Gy. (2015). Investigation of Hungarian Conquest Period (10th c. AD) archery on the basis of activity-induced stress markers on the skeleton - preliminary results. Acta Biologica Szegediensis 59 (1), 65-77.

Torres-Rouff, C. (2003). Oral implications of labret use: A case from pre-Columbian Chile. International Journal of Osteoarchaeology 13, 247-251. https://doi.org/10.1002/oa.691

Turner, G., Anderson, T. (2003). Marked occupational dental abrasion from medieval Kent. International Journal of Osteoarchaeology 13, 168-172. https://doi.org/10.1002/oa.646 